\begin{tabular}{|c|c|c|}
\hline Beitr. Ent. & Keltern & ISSN 0005-805X \\
\hline $\mathbf{6 2}(2012) 2$ & S. $419-426$ & 20.12 .2012 \\
\hline
\end{tabular}

\title{
Further study of Cylindridia CASEY with descriptions of new species
}

\section{(Coleoptera: Curculionidae: Baridinae)}

With 12 figures

Jens Prena

\section{Summary}

Further support is provided for the occurrence of Cylindridia CASEY in the Neotropical realm. The South American Torcus sanguineus Hustache is transferred to Cylindridia (comb. n.). Cylindridia latisquama sp. n., a very similar species and originally included in the type series of T. sanguineus, is described from Argentina and Brazil. Cylindridia andersoni sp. $\mathrm{n}$. is described from Guatemala and Mexico; the species develops inside the culm of Rhychospora sp. cf. macrochaeta (Cyperaceae). The family-group name Torcina Bondar, never satisfactorily distinguished from Limnobaridina CASEY and being based on a misidentified type genus, is placed in synonymy with Zygobaridina Pierce (new synonymy).

\section{Zusammenfassung}

Für das neotropische Vorkommen von Cylindridia CASEY werden weitere unterstützende Fakten vorgelegt. Der südamerikanische Torcus sanguineus Hustache wird Cylindridia zugeordnet (comb. n.). Eine sehr ähnliche und in der originalen Typenserie von T. sanguineus enthaltene Art wird als Cylindridia latisquama sp. n. aus Argentinien und Brasilien beschrieben. Cylindridia andersoni sp. n. wird aus Guatemala und Mexico beschrieben; die Art entwickelt sich im Stengel von Rhynchospora sp. cf. macrochaeta (Cyperaceae). Der Familiengruppenname Torcina Bondar wird mit Zygobaridina PIERCE synonymisiert (syn. n.), da er auf einer Fehlbestimmung basiert und seine orginale Definition sich inhaltlich nicht von der von Limnobaridina CASEY unterscheidet.

\section{Key Words}

Weevils, sedges, Rhynchospora, taxonomy, Neotropics

\section{Introduction}

In an earlier paper (Prena 2006), I argued that the ostensibly Neartic genus Cylindridia Casey, 1920 is principally Neotropical but has one isolated species in North America. This conclusion was based on three new species from high elevations in Central America, considered by me as glacial relicts of a formerly more widespread ancestor, and one unidentified species from southern Brazil. Meanwhile, I have seen additional specimens which not only support this 
conclusion but also help to understand better the existing taxonomic confusion associated with the South American species of this genus. As already suspected in my previous study, it is now confirmed that South American Cylindridia have been described in another genus without making a connection to the Nearctic fauna. Hustache (1939) described at least one Cylindridia species in Torcus Casey, 1922 and placed it in a separate subgenus, Eutorcus, which remained nomenclaturally unavailable because he did not designate a type species for it. I have seen some but not all of his other Torcus species and those do not always belong to Torcus either. The apparently complete reliance on the keys in CASEY (1922) explains why Hustache (1950) speculated about a possible synonymy of Sibariopsida Casey, Sibariops Casey, Pseudotorcus Casey, and Torcus, while at the same time disregarding the more senior name of a strikingly similar North American genus. In this paper I transfer one previously described South American species to Cylindridia, describe two new species, and provide an updated identification key for the seven currently known species. Information on C. fuscipes Prena, C. prolixa (LeConte), C. propinqua Prena, and C. rubripes Prena can be found in Prena (2006).

\section{Acknowledgements}

I am grateful to Bов Anderson (Canadian Museum of Nature, Ottawa) for extracting a good series of a new Cylindridia species from sedges at high elevations in Guatemala and making them available for description. Charlie and Lois O'Brien (Green Valley, AZ) accommodated me in their home in September 2011 for research in their collection. Hélène Perrin (Museum National d'Histoire Naturelle, Paris) made available the type material of two Hustache species which I suspected to be the unidentified "Species A" in Prena (2006). John Brown, Al Norrbom (both Washington, DC), and Charlie O'BRIEN commented on the manuscript.

\section{Material and Methods}

The study is based on more than 500 specimens of Cylindridia and Torcus of authors. The following codens are used to refer to collections in the text.
$\mathrm{AMNH}$
American Museum of Natural History, New York
CMNC Canadian Museum of Nature, Ottawa
CWOB Charles W. \& Lois O’Brien personal collection, Green Valley, Arizona
JPPC
MNHN Jens Prena personal collection, Berlin, Germany
MZSP Museum National d'Histoire Naturelle, Paris
USNM Museu de Zoologia, Universidade de São Paulo, São Paulo, Brazil
UVGC Smithsonian Institution, National Museum of Natural History, Washington, D.C. Universidad del Valle, Guatemala City, Guatemala

The size range of specimens is given as total length (without rostrum) and standard length (anterior margin of pronotum to elytral apex). All measurements were taken with an ocular micrometer in a dissecting microscope. Line-breaks of label-data are indicated as "/ ". 


\section{Results}

Two new Cylindridia species are described below; one discovered recently by Bob Anderson during fieldwork in the Leaf Litter Arthropods of Mesoamerica Project (https://sites.google.com/ site/longinollama/); the other confused with Torcus sanguineus Hustache, 1950. The Hustache Collection has a male and a female specimen standing under this name, each collected in Tigre, Buenos Aires Province, Argentina by M. J. Viana. The type series included at least one other male with fully developed prosternal spines, probably from Luján in the same province, which was not examined by me. The USNM has matching specimens from the same region. The entire material shows that Hustache's male paratype in the MNHN is a distinct species and conspecific with Cylindridia "sp. A" in Prena (2006).

\section{Cylindridia andersoni Prena sp. n.}

\section{Diagnosis:}

Cylindridia andersoni can be recognized by the conspicuous elytral fasciae, which occur in no other known species of Cylindridia. The color pattern is less well defined in the Oaxaca specimens but the male genitalia are identical in both populations.

\section{Description:}

Derm shiny black, appendages rufescent to various degrees, prosternal spines yellowish red; white pyriform setae present on pronotal flank, metepisternum and femur, above eye, and in two elytral fasciae (Fig. 1); rostrum slightly (males) or conspicuously longer (females) than pronotum, very slightly (female) or distinctly (male) curved throughout (Fig. 5), lamellar process ventrad of antennal insertion not angularly projected; antennal club not longer than distal four funicular segments combined; frons with erect setae above eye; pronotum slightly wider than long, sides subtly curved in basal half, roundly constricted apically and tubulate in front; sides of aedeagus gradually converging toward base, apex truncate and medially slightly produced, base of apodemes fused with, but not subsumed in, body of aedeagus; apodeme slightly longer than body of aedeagus (Fig. 9), internal sac short, basal sclerite 2-pronged and minute, tegmen with parameroidal lobes and basal apodeme of subequal length, male sternite 9 with distal appendices unequal; total length 3.0-3.9 mm, standard length 2.7-3.6 mm.

\section{Distribution:}

The species is known from high elevations in Guatemala and Mexico.

\section{Plant associations:}

The specimens from Guatemala were extracted from the culm of a Rhynchospora species, possibly R. macrochaeta STEUdel ex BöcKeler, Cyperaceae.

\section{Epithet:}

The species is named after my Canadian friend and colleague Robert S. Anderson, who found the species inside the host plant.

\section{Material examined:}

Holotype male, dissected, labeled "GUATEMALA: EL PROGRESO/ Cerro Pinalon, Finca Las Nubes/ $2600 \mathrm{~m}, 15.08385^{\circ} \mathrm{N} 89.94258^{\circ} \mathrm{W} / 1-5 . V .2009$. R. Anderson/ cloud forest - various, 
2009-016", "on Rhynchospora cf. macrochaetal Steudel ex Boeckeler/ Cyperaceae - (voucher immature)", "Holotype/ Cylindridial andersonil Prena design. 2012” (CMNC). Paratypes 26: 23 with same data as holotype (CMNC 11, CWOB 2, JPPC 4, USNM 2, UVGC 4); Mexico, Oaxaca, Hwy. 75, 22 mi. [35 km] S Valle Nacional, 5800' [1768 m], 28.V.1983, C. \& L. O’Brien, G. Marshall (CWOB 2, JPPC 1).

\section{Cylindridia latisquama Prena sp. n.}

Torcus sanguineus Hustache, 1939: 117 (partim)

Cylindridia sp. A; Prena (2006: 197)

\section{Diagnosis:}

Cylindridia latisquama is very similar to the equally rufous (and sympatric) C. sanguinea, and both species were represented in the type series of the latter. The simplest way to separate the two species is the dorsal vestiture, which consists of wide, pyriform setae in C. latisquama and of slender, piliform setae in $C$. sanguinea. Another striking though internal difference is that $C$. latisquama has the basal part of the apodemes subsumed into the body of the aedeagus (Fig. 10), which is not the case in C. sanguinea (Fig. 11).

\section{Description:}

Derm reddish brown to brown, head and rostrum darker, matte; whitish pyriform scales present but not locally clustered (Fig. 2); rostrum slightly (males) or conspicuously longer (females) than pronotum, very slightly (female) or distinctly (male) curved throughout (Fig. 6), lamellar process ventrad of antennal insertion not angularly projecting; antennal club slightly longer than distal four funicular segments combined; frons with appressed setae above eye; pronotum slightly wider than long, sides subparallel in basal half, roundly constricted apically and subtubulate in front; sides of aedeagus parallel, apex blunt and medially slightly produced, base of apodemes subsumed into body of aedeagus, remaining free section of apodeme shorter than body of aedeagus (Fig. 10), internal sac more than half length of apodeme and lobed, basal sclerite absent, tegmen with parameroidal lobes and basal apodeme of subequal length, male sternite 9 with distal appendices unequal; total length $3.5-5.6 \mathrm{~mm}$, standard length $3.2-5.3 \mathrm{~mm}$.

\section{Distribution:}

The species is known from southern Brazil and Argentina.

\section{Plant associations:}

\section{Unknown.}

\section{Epithet:}

The name is a Latin composite noun in apposition based on squama (scale) and latus (wide).

\section{Material examined:}

Holotype male, dissected, labeled "BRASIL: Nova/ Teutonia, Santa/ Catarina, X./ 1974, F. Plaumann" (CMNC). Paratypes 31: 29 with same data as holotype (CMNC 13, CWOB 4, JPPC 4, MNHN 2, MZSP 4, USNM 2); Argentina, Buenos Aires, Tigre, 1938, M. J. Viana [= paratype of Torcus sanguineus Hustache] (MNHN 1); Argentina, Buenos Aires, San Fernando, X/1955, J. Daguerre (USNM 1). 
Cylindridia sanguinea (HUSTACHE), comb. n.

Torcus sanguineus Hustache, 1939: 117.

\section{Diagnosis:}

Cylindridia sanguinea (Fig. 3, 7) can be confused with C. latisquama (Fig. 2, 6; see diagnosis of that species) and possibly Torcus variabilis (Fig. 4, 8), which has similar vestiture and habitus. The latter can be distinguished easily by the row of erect white setae above the eye. All male C. sanguinea from San Fernando have the prosternal spines abruptly bent at the base (the specimen from Tigre is a dwarf male without spines), but it is not known if this character varies between local populations. The specimens measured 3.5-4.7 $\mathrm{mm}$ (standard length 3.2-4.3 $\mathrm{mm}$ ) and were approximately in the same size range as C. latisquama and T. variabilis.

\section{Distribution:}

This species has been collected in Buenos Aires Province, Argentina.

\section{Plant associations:}

\section{Unknown.}

\section{Material examined:}

ARGENTINA: Buenos Aires, Tigre, VI/1938, M. J. Viana, holotype (MNHN 1), San Fernando, XI/1962, J. Daguerre (USNM 14). Total 15 specimens.

\section{Key to the known species of Cylindridia}

1 Elytron with basal and submedian fasciae of white, squamiform setae; frons above eye with row of erect, squamiform setae; Mexico and Guatemala, mid and high elevations

C. andersoni

- $\quad$ Elytron with setae evenly distributed when present, not arranged in fasciae; frons above eye at most with inconspicuous setae; more widely distributed 2

2 Integument dark green to cupreous, with strong metallic luster; body glabrous, without discernable setae; Central America, high elevations between 2000-3100 m 3

- Integument rufous to black, without strong metallic luster; body usually with distinct setae (C. prolixa from North America with microscopic setae); temperate zones of North- and South America, low elevations

3 Antennal club compact, approximately as long as distal four funicular segments combined; femora dark metallic, tibiae and tarsi red; southern Mexico

C. propinqua

Antennal club more elongate, at least as long as distal five funicular segments combined; legs of uniform color, either dark metallic or reddish; Costa Rica

4 Legs red; elytral stria 10 not impressed subdistally; rostrum as long as or longer than pronotum; male without angularly projecting lamellar process ventrad of antennal insertion; female with rostrum weakly curved throughout

- $\quad$ Legs dark metallic; elytral stria 10 impressed subdistally; rostrum shorter than pronotum; male with angularly projecting lamellar process ventrad of antennal insertion; female with rostrum notably curved in distal one-third 
5 Integument black and almost glabrous, setae usually microscopic; North America

C. prolixa

- Integument rufous to dark brown, elytral interstriae always with conspicuous setae; southern South America 6

6 Body slightly more elongate; elytral interstriae with wide, pyriform setae; female rostrum longer and less curved (Fig. 6); male prosternal spines more evenly curved at base; body of aedeagus longer than basal apodemes

C. latisquama

Body slightly stouter; elytral interstriae with piliform setae; female rostrum shorter and more curved (Fig. 7); male prosternal spines abruptly bent at base; body of aedeagus shorter than basal apodemes

C. sanguinea

\section{Discussion:}

As presently defined, Cylindridia includes seven species which, taken together, show a noticeably disjunct distribution in the New World. All lowland records in each hemisphere are from the temperate zone, and all records within the tropics are from mid and high elevations in Central America. Even though the newly added data improve our understanding of these slender, sedge-associated species, their morphological distinctness from other genera remains unclear. This problem has been mentioned previously in connection with the Nearctic genus Dirabius Casey, 1920 (Prena 2006). Several morphologically similar species occur in the temperate zone of South America but differ in details which are difficult to interpret with the presently available material. This includes, for example, the other two species described by Hustache (1950) in his unavailable subgenus Eutorcus. One of them, Torcus variabilis Hustache, 1950 (Fig. 4), is well represented in collections (e.g., AMNH, CWOB, MNHN, and USNM) and was studied in greater detail. Unlike typical Cylindridia, T. variabilis has a distally tapered aedeagus (Fig. 12), which occurs regularly in other sedge- and grass-associated baridines, particularly in the Lipancylus/Parallelosomus complex. Further collections as well as biological and molecular data are needed to clarify whether Cylindridia indeed evolved through biogeographic segregation of a formerly more widespread temperate fauna or represents species with convergently elongate body shapes derived from unrelated ancestors in cooler climates.

The partially synonymous usage of the names Cylindridia and Eutorcus warrants a brief review of the history of their classifications. Cylindridia has been treated under Madopterini: Zygobaridina by Alonso-Zarazaga \& Lyal (1999) and Anderson (2002), and Eutorcus has been treated under Madopterini: Torcina by Bondar (1943), Wibmer \& O’Brien (1986), and Alonso-Zarazaga \& Lyal (1999). These two subtribal names are tightly connected with a third name, Limnobaridina. Bondar (1943) originally proposed Torcina [spelled Torcocina] as a subtribe of Limnobaridini [spelled Limnobarini]. Alonso-Zarazaga \& Lyal (1999) considered Limnobaridina as a synonym of Zygobaridina but maintained Torcina as valid. Bondar's Torcina was based on specimens identified as Torcus by Hustache (Bondar 1943, p. 78) and those are not congeneric with CASEY's type species. Because Torcina is based on a misidentified type species and Bondar's original diagnosis fully applies to Limnobaridina, I relegate Torcina into synonymy with Limnobaridina (new synonymy), the latter itself presently being a synonym of Zygobaridina. The monophyly of Zygobaridina + Limnobaridina remains to be tested. 


\section{References}

Alonso-Zarazaga, M. A. \& Lyal, C. H. C. 1999: A world catalogue of families and genera of Curculionoidea (excepting Scolytidae and Platypodidae). - EntomoPraxis S.C.P., Barcelona: 316 pp.

Anderson, R. S. 2002: Curculionidae. - In: Arnett R. H. JR.; Thomas M. C.; Skelley P. E. \& Frank, J. H.: American Beetles Vol. 2. CRC Press, Boca Raton, London, New York, Washington DC: pp. 722-815.

Bondar, G. 1943: Notas Entomológicas da Baía. XI. - Revista de Entomología, Rio de Janeiro 14: 33-84.

CASEY, T. L. 1922: Studies in the rhynchophorous subfamily Barinae of the Brazilian fauna. - Memoirs on the Coleoptera, Lancaster 10: 1-520.

Hustache, A. 1939: Curculionides nouveaux de l'Argentine et autres régions Sud-Américaines. - Anales de la Sociedad Científica Argentina, Buenos Aires 128: 38-64, 99-124.

Hustache, A. 1950: Nouveaux Barinae Sud Américains. Troisième partie - Centrinina. - Boletim do Museu Nacional, Rio de Janeiro (Nova Serie) [1949] 97: 1-143.

Prena, J. 2006: A preliminary study of Cylindridia Casey, with descriptions of new species from Middle America (Coleoptera: Curculionidae: Baridinae). - Beiträge zur Entomologie, Keltern 56: 189-198.

Wibmer, G. J. \& O'Brien, C. W. 1986: Annotated checklist of the weevils (Curculionidae sensu lato) of South America (Coleoptera: Curculionoidea). - Memoirs of the American Entomological Institute, Gainesville 39: i-xvi, 1-563.

\section{Author's address:}

Jens Prena

Systematic Entomology Laboratory

c/o National Museum of Natural History

Washington, D.C. 20013-7012, U.S.A.

e-mail: baridinae@gmx.de

\section{Subject Editor:}

Prof. Dr. C. W. O’BRIEN 


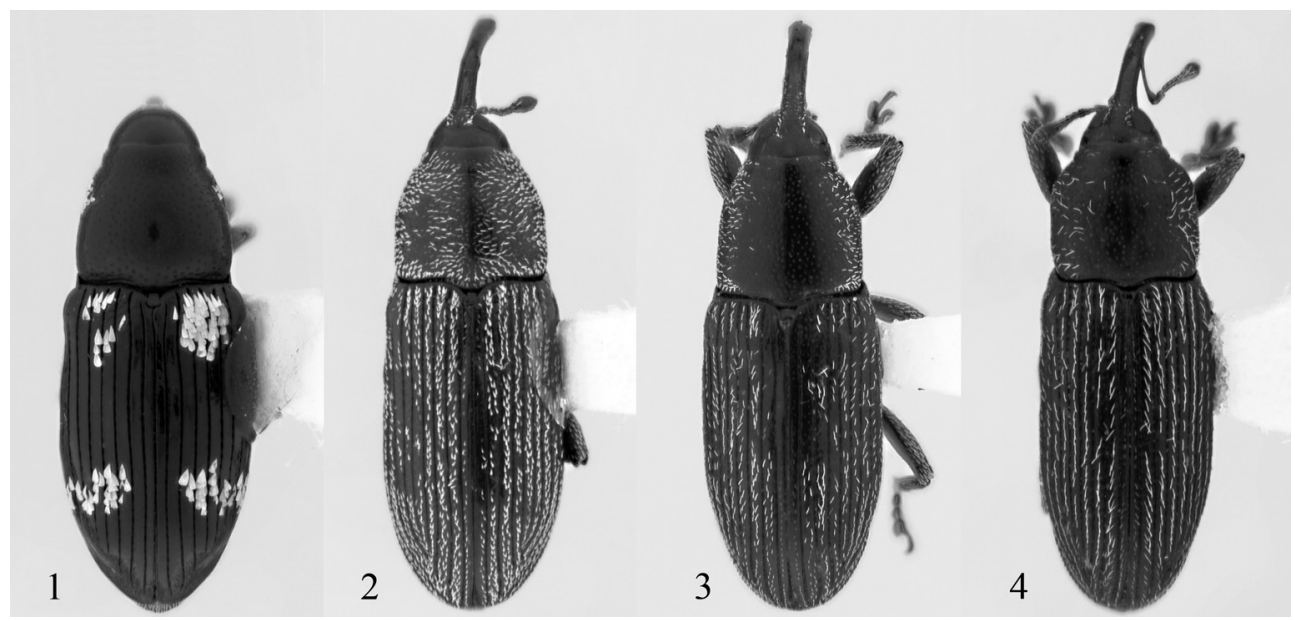

Fig. 1-4: Dorsal habitus of female. 1, Cylindridia andersoni $(\mathrm{L}=3.8 \mathrm{~mm}) ; 2$, C. latisquama $(\mathrm{L}=5.0 \mathrm{~mm})$; 3. C. sanguinea $(\mathrm{L}=4.2 \mathrm{~mm})$; 4 , Torcus variabilis $(\mathrm{L}=3.9 \mathrm{~mm})$.
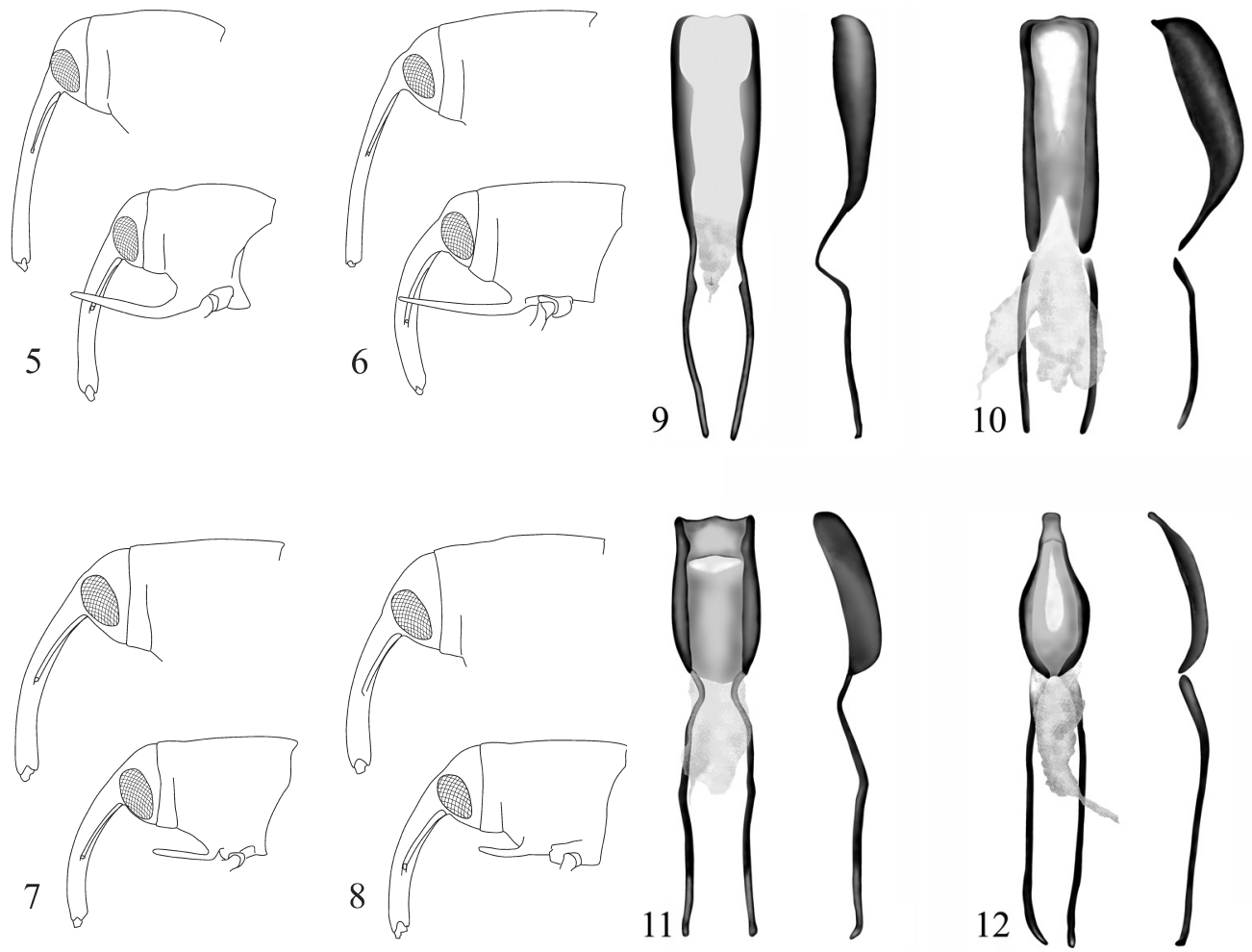

Fig. 5-8: Head and prothorax, lateral view, of female (top) and male (bottom). 5, Cylindridia andersoni; 6, C. latisquama; 7, C. sanguinea; 8 , Torcus variabilis.

Fig. 9-12: Aedeagus, dorsal (left) and lateral (right) views. 9, Cylindridia andersoni; 10, C. latisquama; 11, C. sanguinea; 12 , Torcus variabilis. 